九州大学学術情報リポジトリ

Kyushu University Institutional Repository

\title{
Comparison of Soy Protein Dope with Yeast Protein Dope on the Rheological Properties
}

Hayakawa, Isao

Laboratory of Food Technology, Faculty of Agriculture, Kyushu University

Chang, Hung Min

Laboratory of Food Technology, Faculty of Agriculture, Kyushu University

Katoh, Tatsuo

Laboratory of Food Technology, Faculty of Agriculture, Kyushu University

https://doi.org/10.5109/23788

出版情報：九州大学大学院農学研究院紀要. 28 (4)，pp. 185-192，1984-03. Kyushu University バージョン：

権利関係 : 


\title{
Comparison of Soy Protein Dope with Yeast Protein Dope on the Rheological Properties
}

\author{
Isao Hayakawa, Hung Min Chang and Tatsuo Katoh \\ Laboratory of Food Technology, Faculty of Agriculture, \\ Kyushu University 46-09, Fukuoka 813 \\ (Received Decenber I)
}

\begin{abstract}
Rheological properties of isolated soybean protein dopes were compared with those of yeart protein dopes in order to find out their application and processing. The elastic properties of soybean protein dope were better than those of yeast protein dope prepared with high protein concentrates because the viscoelastic absorption of soybean protein dope was smaller than that of yeast protein dope and the capacity of water holding was higher than that of yeast protein dope. On the other hand, yeast protein dope had bigger loss tangent values since lipids in the yeast protein accelerate into slippage among intermolecular of the protein dope. Two kinds of dopes prepared with soybean protein and yeast protein were regarded as belonging to Maxwell model in a limited range of protein concentration.
\end{abstract}

\section{INTRODUCTION}

Physical properties of food not only assume largely the control of food quality evaluation, but also play an important role in process administration such as transportation and texture in manufacturing process (Sobue et al., 1969, Yamamoto, 1965a,1965b, Suzuki et al., 1973, Hayakawa, 1983). In fact, food which is chemically and physically designed to very subtly contains many field of extreme complication and unsolved problems as compared with the relationships between quality of polymer and its rheological properties for synthetic polymers, which is composed of single ingredient (Hayakawa et al., 1972, Khai et al., 1974, Katsuta and Hayakawa, 1983). Thus rheological studies on food science are far behind in comparison with synthetic polymer field.

In this report, thermal and mechanical characteristics of protein dope are clarified through the rheological experiments of isolated soybean protein and yeast protein prepared with Impact-Cell-Mill method developed by Hayakawa, and experimerimental data were obtained to find out new application and processing for these proteins.

\section{MATEKIALS AND METHODS}

1) Isolated soybean protein (soy protein; protein contents; $90.1 \%$, NSI: over 85) was prepared from deflated soybean meal obtained from Showa Sangyo Co., Ltd. 
2) Sodium hydroxide, and other reagents used were of analytical grade and obtained from Wako Pure Chemical Industries Ltd.

3) Yeast prothein was prepared from a commercial baker's yeast (Kanegafuchi Chemical Industry Co., Ltd.) by using Impact-Cell-Mill method developed by Hayakawa and Inagami (1972).

4) The dope was prepared by mixing 5-20 \% protein concentrates and 0-2.0 sodium hydroxide with a Polytron PT-45 (Kinematica Co., Switzerland).

5) Viscoelastic properties were measured with a 3D rheometer manufactured by Iwamoto Seisakusho Co., Ltd, and was calculated by the equation of the proposed Markovitz's equation (KōbunshiGakkai Rheology linkai, 1965) and the data were analyzed with a computer Sord M23 Mark III (Sord Computer System, Inc.).

\section{RESULTS AND DISCUSSION}

\section{Effects of protein concentrates on dynamic viscoelasticity}

The rheological properties of dopes prepared with soybean protein (soy protein) and yeast protein were measured under the influences of hydroxide ion concentrates, temperature, salt concentrates and also protein concentrates.

As the protein concentrates effect directly on rheological properties of dope, viscoelastic properties of each dope indicate higher values as the protein concentrates increased in the dope. The results are shown in Fig. 1 and in Fig. 2.

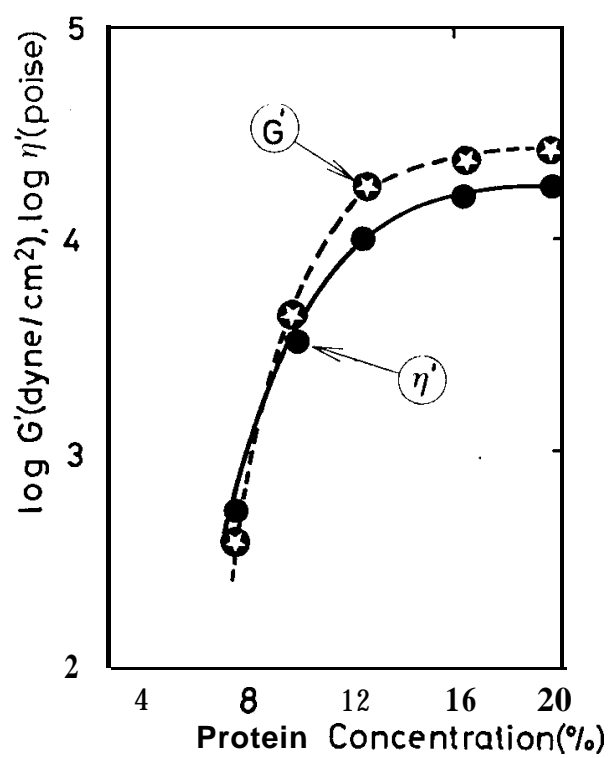

Fig. 1. Effects of protein concentration on dynamic viscoelasticity of yeast protein dope at $\mathrm{pH} 10.1,21^{\circ} \mathrm{C}, 0.2 \mathrm{~Hz}$. 


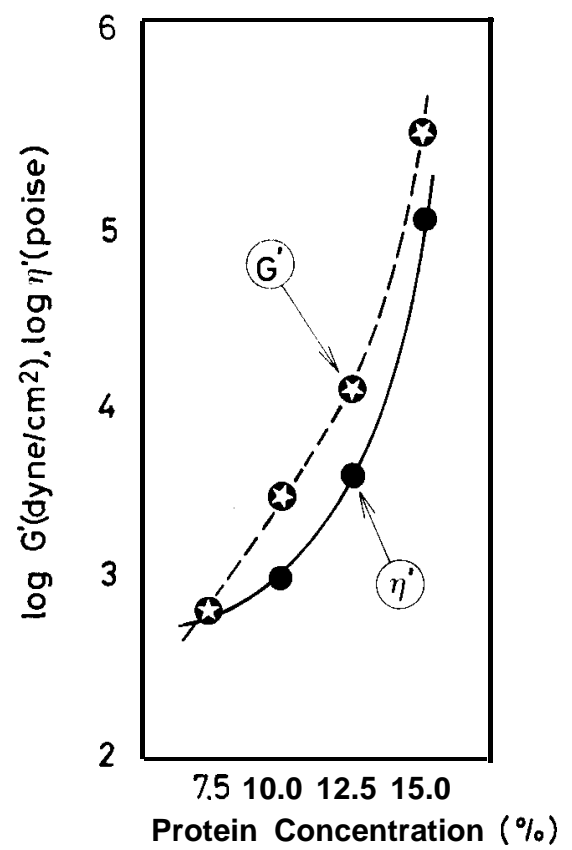

Fig. 2. Effects of protein concentration on dynamic viscoelasticity of soy protein dope at same experimental conditions in Fig. 1.

When the concentration of yeast prothein dope is below 7 or over about $15 \%$, the accurate measurement of dope for viscoelasty was difficult, due to great influence of plasticity component on it. Especially, molecular weight of yeast protein is bigger than that of soy protein and casein by the gel filtration chromatogram (Hayakawa et al., 1978, Katsuta et al., 1982) and its solubility is also no good. Thus the dope of yeast protein was inferior to any of the soy protein dope in the viscoelasticity and especially in the gel texture at high protein concentrates. The higher concentration of soy protein dope shows the better viscoelastic behavior, and developed into rubberlike elasticity with increasing alkali concenrates.

\section{Effects of alkali on the viscoelastic properties}

Since the $\mathrm{pH}$ of the dope is related with the progress of unfolding of protein molecule, viscoelasticities of dope are significantly affected by it and the results were shown in Fig. 3 and in Fig. 4.

The viscoelastic behavior of yeast protein dopes were not excellent, colour of them was white brown and the solubility of yeast protein was less than that of the soy protein. Yeast protein needed long maturation time and more sodium hydroxide to prepare a good viscoeiastic dope.

On the other hand, as shown in Fig. 4, the soy protein dope was more stable than yeast protein against alkali concentrates, the alkali effection on 


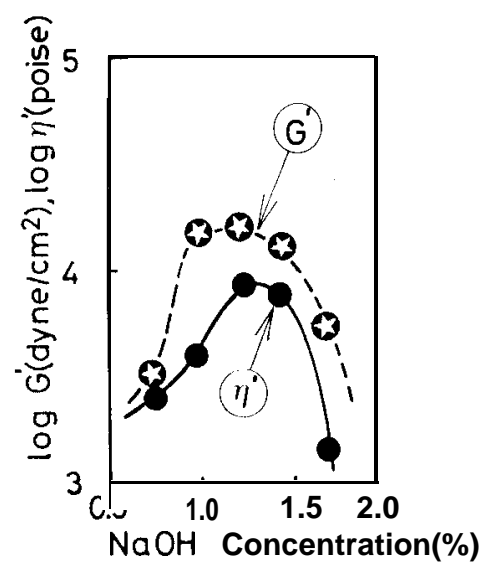

Fig. 3. Effects of alkali on dynamic viscoelasticity of yeast protein dope al $12.5 \%$ protein cocentration, $21^{\circ} \mathrm{C}$, $0.2 \mathrm{H} z$. Symboles in this figure are the same as in Fig. 1 and in Fig. 2.

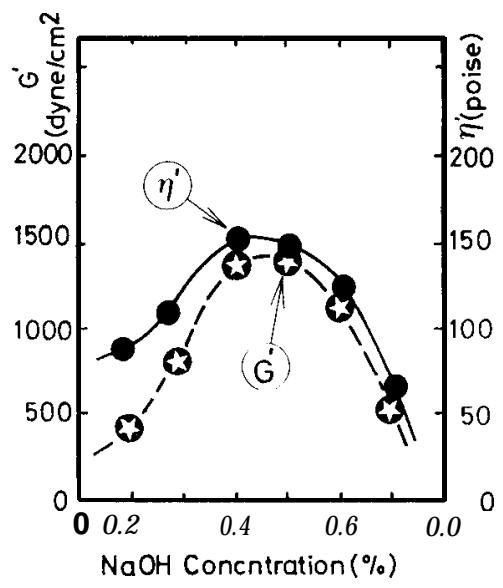

Fig. 4. Effects of alkali on dynamic viscoelasticity of soybean protein dope at $8.2 \%$ protein concentration, $21^{\circ} \mathrm{C}, 0.2 \mathrm{~Hz}$. Symboles in this figure are the same as in Fig. 3.

it was quite little. Of course, the viscoelastic values of dope prepared with high alkali concentrates were lower than those prepared with low alkali concentrates because the protein was hydrolyzed with alkali and the molecular weight decreased.

\section{Effects of temperature on loss tangent}

In odrr to grasp the internal condition of dope, temperature dependence were investigated by positioning of $\tan \delta$ of viscoelastic behavior, becauses as polymer-s, crystalline properties and structure of material are assumed from absorptions of viscoelastic behaviors, and present method is applied to study this field. The relationships by changing the temperature between loss tangent $(\tan \delta)$ and protein concentrates were studied. The results a $\mathrm{r} c$ shown in Fig. 5 and in Fig. 6. The curves of soy protein dope were quitc different from those of yeast protein dope and also from those of casein as seen in the above figures. The yeast protein indicated extreamly sharp peak between $15-30^{\circ} \mathrm{C}$, but such characteristic phenomenon did not occur in the soy protein dope and also in the casein dope. The absorption of yeast protein dope shifted from low temperature side to high temperature side with increasing protein concentrates. Because intermolecular slippage of protein dope is promoted by fats and lipids. This phenomenon caused the absorption.

From mentioned above, dope of casein and soy protein did not show any kind of absorption on the curve of $\tan \delta$. This corresponds with absorption phenomena of viscoelastic body like a curve of polybutene-I (Yasuda and Talayanagi 1964). Thus the absorption peak of yeast protein dope is caused by the decrement of $\mathrm{G}^{\prime}$, as the absorption phenomena of viscoelastic behavior 


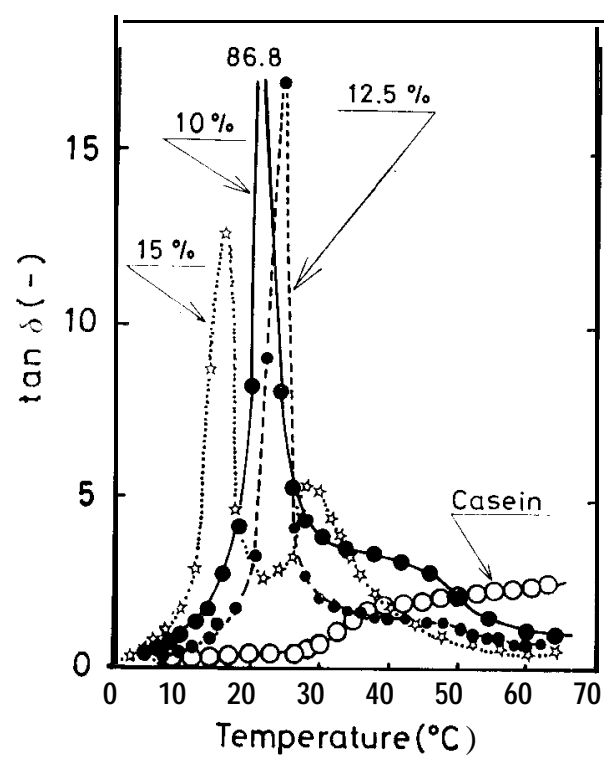

Fig. 5. Dielectric loss tangent of years protein dope against temperature at $\mathrm{pH}$ 10.8 and at $0.3 \mathrm{~Hz}$.

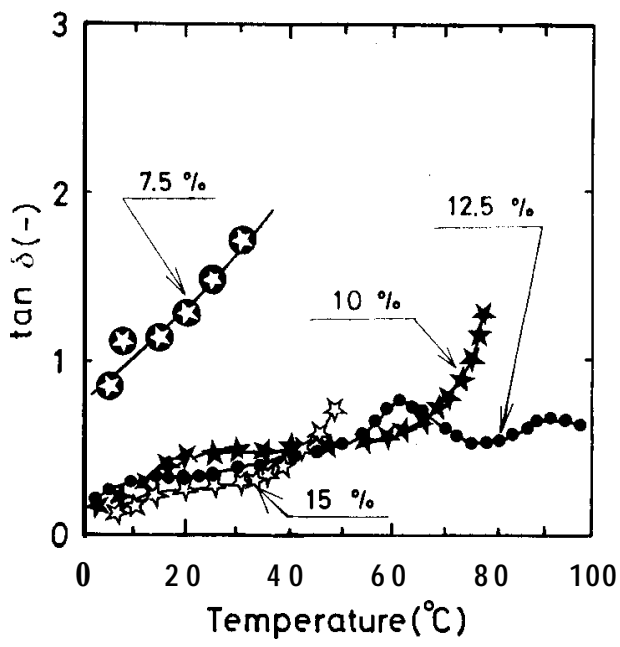

Fig. 6. Dielectric loss tangent of soy protein dope against temperature at $\mathrm{pH}$ $10.2,0.3 \mathrm{~Hz}$.

observed in the vicinity of normal temperature can be regarded as the slippage of lipids acted as slip additivess in the dope. The decrement of ' ${ }^{\prime}$ indicates that intermolecule slippage of protein dope produces abnormal flow phenomenon between $16-30^{\circ} \mathrm{C}$ (refer to Fig. 8).

The dope prepared with $7.5 \%$ concentrates of soy protein showed a small and broad absorption. The absorption of it was smaller compared with yeast protein's. The temperature dependence of both $\mathrm{G}^{\prime}$ and $\mathrm{G}^{\prime \prime}$ were not so big. However, the soy protein dope showed lager values of $\mathrm{G}^{\prime}$ and $\mathrm{G}^{\prime \prime}$ and $\tan \delta<$ 1 , so it has better properties such as strongness and flexibility than yeast protein dope's (refer to Fig. 2).

Fig. 7 shows temperature dependence of $\tan \delta$ of $14.9 \%$ yeast protein dope at $0.3 \mathrm{~Hz}$. The value of tan $\delta$ was small when the $\mathrm{pH}$ value was low. When the $\mathrm{pH}$ was 10.7, tan $\delta$ was measured to 83.9 but then later decreased sharply when temperature was increased to $40^{\circ} \mathrm{C}$. When $\mathrm{pH}$ was increased to 11.3, the $\tan \delta$ was 5.4. Since the alkali concentrates are closely related with the $\tan \delta$, so it can be considered to have close relationships with three dimensional structure and unfolding progress of protein molecules. The distribution curve of viscoelastic behavior $(0.3 \mathrm{~Hz})$ was shown in Fig. 8 . In the neutral pH sample, the viscoelastic absorption was broad, but when the $\mathrm{pH}$ was increased over 10, it first became narrow and then became broad with increasing $\mathrm{NaOH}$ concentrates. The flow of protein molecule in the dope was observed greatly when the $\mathrm{pH}$ was at 10 and 10.7 respectively, and then decreased abruptly over $\mathrm{pH}$ 11.3. Because it was considered that stabi- 


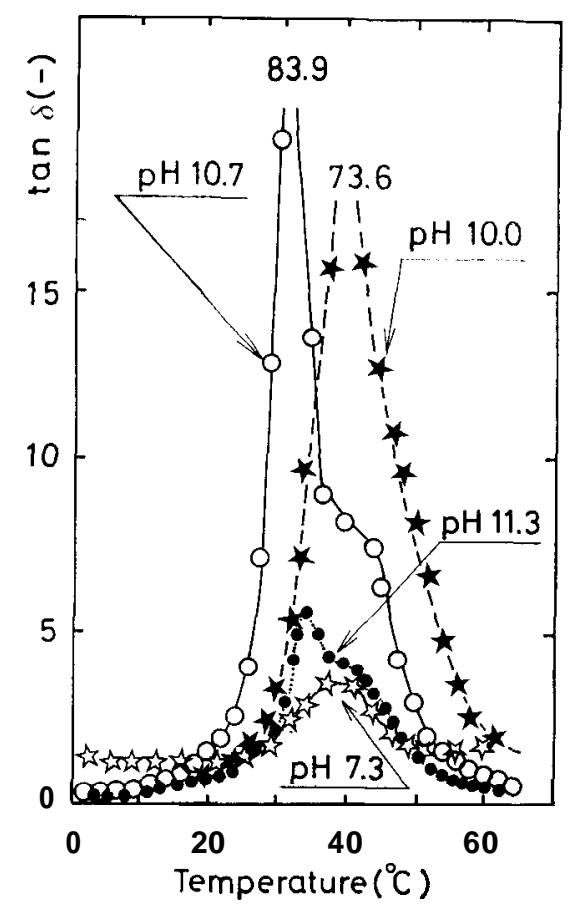

Fig. 7. Effects of alkali on dielectric loss tangent of yeast protein dope at $14.9 \%$ protein concentration, $0.3 \mathrm{~Hz}$.

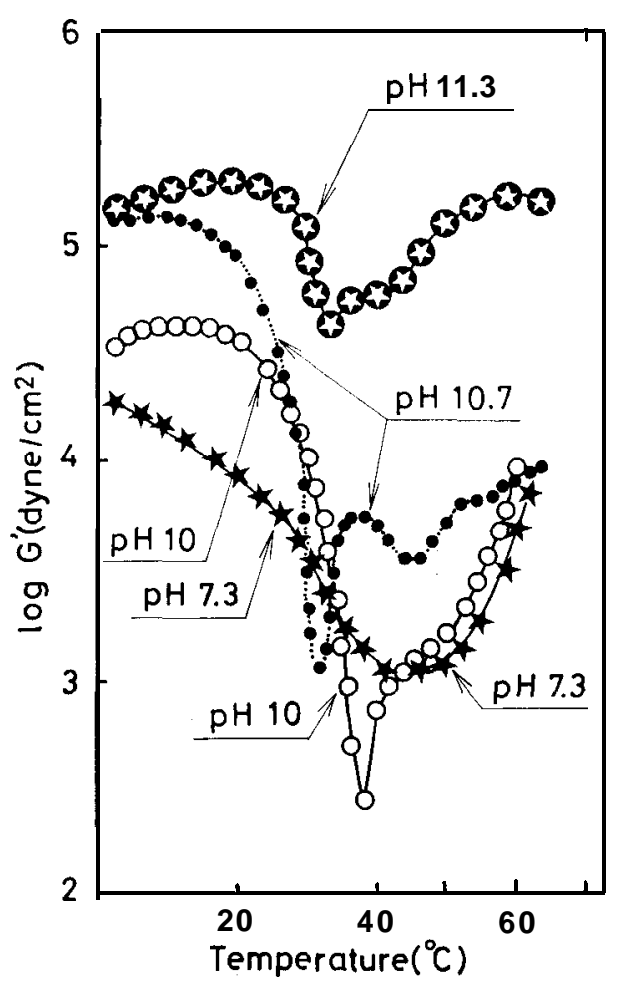

Fig. 8. Temperature dependence of 14.9 of yeast protein dope on the dynamic elasticities at $0.3 \mathrm{~Hz}$.

lization of the dope was due to the frequency of dynamic measurement with increasing $\mathrm{NaOH}$ concentrates, small protein particles developed into homogeneous colloidal protein dope with increasing alkali concentrates. It is clear that contribution ratio of elastic component of yeast protein dope is bigger than that of soy protein.

\section{Charactersitics of frequency dependence}

Frequency dependence of the dopes prepared for present research was

$$
\begin{array}{lc}
G^{\prime}=\frac{G(\omega \tau)^{2}}{1\left(+(\omega \tau)^{2}\right)} & G^{\prime \prime}=\frac{G(\omega \tau)}{\left(1+(\omega \tau)^{2}\right)} \\
\tau-G^{\prime} & G^{\prime \prime}=\frac{G^{\prime}}{\omega \tau} \\
\omega^{2} \eta^{\prime} & =\omega \eta^{\prime}
\end{array}
$$

assumed that the protein dopes are single model of Maxwell. The results are shown in Fig. 9. Singel model of Maxwell is showed by $G^{\prime}=G(\omega \tau)^{2}$ / $\left(1+\omega^{2} \tau^{2}\right), G^{\prime \prime}=G(\omega \tau) /\left(1+\omega^{2} \tau^{2}\right)$. Data of $G^{\prime} / G$ and $G^{\prime \prime} / G$ indicate 0.5 of $Y$ axis 


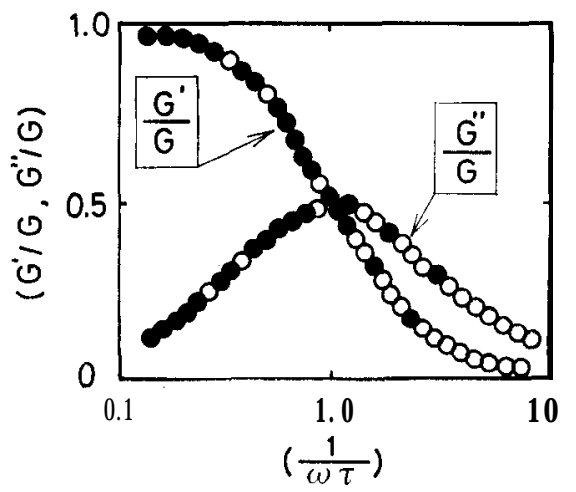

Fig. 9. Frequency dependency for protein dopes in temperature dispersion. White circle is yeast protein and black circle is soy protein.

at or $-\mathrm{I}, \mathrm{G}^{\prime} / \mathrm{G}$ is dispersed at $\frac{1}{\omega \tau}=0$, and $\mathrm{G}^{\prime \prime} / \mathrm{G}$ indicates the minimum value at $\frac{1}{\omega \tau}=0$ and $\frac{1}{\omega \tau}=10$. Thus the protein dope indicates excellent viscoelastic movement as a single model of Maxwell body in a extremely limited range. The yeast protein is or $<1$ for the case of soybean protein $\omega \tau>1$.

From these results, the following conclusion can be made. That is to say, the dope of yeast protein made with Impact-Cell-Mill method has larger frequency dependence, combination of inter protein molecules is weak since tan $\delta$ is larger. From the above mentioned, yeast protein dope is more fluid than soy protein dope, by assistance of fats and lipids, that is an advantage point as paper coating materials. On the other hand, soybean protein has an advantage point to the preparation of gelation and high water contents foods.

\section{ACKNOWLEDGEMENTS}

The assistance of Showa Sangyo Co., Ltd. and Kanegafuchi Chemical Industry Co., Ltd. by providing the samples are greatly appreciated by the authors.

\section{REFERENCES}

Hayakawa, I. and K. Inagami 1972 An isolation method of protein from single cell by Impact-Cell-Mill. Nippon Shokuhin Kogyo Gakkaishi, 19: 9-15

Hayakawa, I., N. D. Khai, E. Imamura and D. Nomura 1972 A method for the isolation of protein from single cell using the Impact-Cell-Mill. J. Ferment. Technol., 50: 354360

Hayakawa, I. 1983 Rheological properties of dope and its fiber formation. New Food Industry (In Japanese), 25(4): 63-79

Hayakawa, I. and D. Nomura 1978 Effect of surfatants on spinnability and rheological properties of single cell protein (SCP). Agri. Biol.Chem., 42: 17-Z

Katsuta, K. and I. Hayakawa 1982 Spinnability and rheological properties of soy pretcin. Nippon Nogeikagaku Kaishi, 56: 189-194 
Katsuta, K. and I. Hayakawa 1933 Studies on the spun-fiber strength of soy protein. Nippon Shokuhin Kogyo Gakkaishi, 30 : 264-269

Khai, N. D., I. Hayakawa and D. Nomura 1974 The application of low molecular weight yeast protein to paper coating. J. Ferment. Technol., 52: 399-407

Kobunshi Gakkai Rheology Iinkai 1965 Measurement of viscolasticity. In "Rheology Measurement”, ed. by Kobunshi Gakkai Rheology Iinkai, Kyoritsu Syuppan, Tokyo, pp. 46 (In Japanese)

Sobue, H., K. Matsuzaki, K. Murakami and Y. Tabata 1969 Spinning and film formation. In "Kagakuseni no boushi to film no keisei (II)“, cd. by Kobunshi Gakkai, Chijin Syokan, Tokyo, pp. 79-356 (In Japanese)

Suzuki, S., et al. 1973 Tatorui no bussei to sonokenkyuhou. In "Sogo tatorui kagaku", cd. by Harada, et al,, Kodansha, Tokyo, pp. 297 -412 (In Japanese)

Yamamoto, T. 1965 Kneading. In "Food Engineering Hand Book", cd. by Teramoto, Asakura Shoten, Tokyo, pp. 311-342 (In Japanese)

Yamamoto, T. 1965 Forming. In "Food Engineering Hand Bood", ed. by Teramoto, Asakura Syoten, Tokyo, pp. 343-369 (In Japanese)

Yasuda, H. and M. Takayanagi 1964 Mechanical dispersion of polybutenc-I. Reports on Progress in Polymer Physics in Japan, 1: 245-248 